\title{
Re-Engineering Sustainable Rural Economy Through Socio- Infrastructural Facilities In Nigeria.
}

\author{
Edeh Joseph N. (Ph.D) Nwakamma Michael C. Ugbala Kenneth (Ph.D) \\ Department Of Public Administration Ebonyi State University, Abakaliki
}

\begin{abstract}
The Paper Is Titled "Re-Engineering Sustainable Rural Economy Through Social Infrastructural Facilities In Nigeria". The Objective Of The Study Was To Establish The Nexus Between Social Infrastructure Like Basic Education, Health Care Facilities, Provision Of Clean Source Of Drinking Water, Housing, Poverty Reduction, Human Capital Development Etc, And Sustainable Rural Economy. Content Analytical Method Was Adopted To Review Relevant Literature In Order To Link The Study With The Existing Views On Related Topics. The Paper Adopted The People Centered Theory Propounded By Korten (1984) As The Theoretical Framework Of Analysis. The Key Elements Of The Approach Are Provision Of Infrastructure Through (A) The Empowerment Of People (B) Participation And (C) Sustainability Among Others. The Choice Of The Approach Was Based On The Fact That The Components Of People Centered Approach Are Vital Factors For Sustainable Rural Economy. The Researchers Found That Poor Condition Of Life In The Rural Areas Is As A Result Of Inadequate Provision Of Social Infrastructural Facilities And Therefore Recommended A Total Overhaul Of Governments Approach To Development In Order To Improve The Economy Of The Rural People. Participatory Approach Should Be Adopted. Government Should Improve Access To Education, Healthcare Facilities, Quality Road Network In The Rural Areas. The Rural People Must Participate In Taken Developmental Decisions That Affect Their Lives As Development Is A Learning And Participatory Process.
\end{abstract}

Key Words: Development, Sustainable Development, Infrastructure, Social Infrastructure And Rural Economy.

\section{INTRODUCTION}

Efforts At Rural Development In Nigeria Dates Back To Colonial Period. Since Then To Date, Bold Attempts Have Been Made To Open Up The Rural Areas Of The Country Where Over 75 Percent Of The Population Live And Earn Their Livelihood, But Inspite Of Several Efforts Made, The Rural Areas Of The Nation Have Still Not Shown Much In Response. It Is Still Marred By Many Disabilities. These Range From Remoteness, Inaccessibility, Relative Isolation, Poverty And Unbroken Monotony Of Daily Life, Loss Of Active Population Through Rural Urban Migration, Malnutrition Diseases And Relative Lethargy (Adefolalu,1997).

We Are Concerned With The Development And Growth Of Rural Economy Because No Meaningful National Development Can Take Place Without A Strong Based Rural Economy. This Understanding Perhaps, Motivated Successive Governments In Nigeria To Embark On One Rural Development Programme Or The Other In The Pursuit Of Sustainable National Development. These Include: Operation Feed The Nation (Ofn) Associated With The Obasanjo Reign; The Green Revolution Of The Shagari Administration. The War Against Indiscipline (Wai), Of The Buhari Fame And The Directorate Of Food, Roads And Rural Infrastructure (Dfrri) Of The Babangida Administration. To Implement These Programmes Many Organizations And Institutions Were Established. These Include The River Basin And Rural Development Authorities (Rbrdas), Agricultural Development Projects (Adps); Community Banks, Peoples Bank Of Nigeria, Better Life Programme, National Directorate Of Employment (Nde) And Guinea Worm Eradication Force; There Is Also The Subsidy ReInvestment Programme (Sure-P), National Eradication Programme And The (Napep) That Also Geared Towards Improving The Living Standard Of Nigerians. These Programmes Made Little Impact In Terms Of ReEngineering Rural Economy. This Manifests In Low Level Of Development Of Rural Areas In Nigeria. It Has Been Argued That Sustainable Rural Economy Requires Certain Infrastructural Facilities.

A Sustainable Rural Economy Is The Pursuit Of An Efficient Mobilization And Utilization Of Available Human And Material Resources In The Rural Area To Produce Goods And Services To Meet The Needs Of The Present Generation Without Compromising The Ability Of The Future Generations From Meeting Their Own Needs. According To Lasisi (1992), This Involves The Mobilization And Allocation Of Resources So As To Reach A Desirable Balance Over Time Between Welfare And Productive Services Available To The Rural Population, Mass Participation Which Requires Resources Allocation To Low-Income Regions And Classes And That Productive And Social Services Actually Reach Them; And Making The Process Self-Sustaining Which Includes Development Of The Appropriate Skills And Implementing Capacity, 
And The Presence Of Institutions At The Local, Regional And National Levels To Ensure The Effective Use Of Existing Resources And Foster The Mobilization Of Additional Finance And Human Resources For Continued Development Of The Subsistence Sector.

Re-Engineering Rural Economy Will Hardly To Place Where Social And Physical Infrastructure Are Not Adequately Provided, Especially To Boost Agricultural Production. This Is Because Up To 80 Percent Of The Over 160 Million Population In Nigeria Resides In The Rural Areas. Agriculture Is The Mainstay Of The Economy Contributing About 40 Percent Of Gdp. The Agricultural Sector Employs Approximately Two-Thirds Of The Country's Total Labour Force And Provides Livelihood To About 90 Percent Of The Rural Population. About 90 Percent Of Nigeria Food Is Produced By Small-Scale Formers Who Cultivate Small Plots Of Land And Depend On Rainfall Rather Than Irrigation System.

That Was Why The African Development Bank (Adp) Has Made Infrastructure Development A Cornerstone In Its Development Agenda With Regional Member Countries (Tmsa, 2012). The Bank Recognized That Lack Of Adequate Social And Economic Infrastructure Is One Of The Key Constraints To Development In Africa. Unfortunately, Such Social Infrastructure As Good Roads, Health Care Facilities, Electricity, Capacity Building Institutions, Education, Training And Development Centers, Sanitation Services, Clean And Portable Water, Etc Are Not Adequately Provided Especially In The Nigeria Rural Areas. Ifad In Its 2012 Report Maintains That Rural Infrastructure In Nigeria Has Long Been Neglected. Investments In Health, Education, And Water Supply Have Been Focused Largely On The Cities. As A Result, Rural Population Has Extremely Limited Access To Services Such As Schools And Health Care Centres And About Half Of The Population Lacks Access To Safe Drinking Water. Rural Economy Has Taken A Downturn Despite Efforts By Successive Government In Nigeria To Improve The Socio-Economic Wellbeing Of The People Especially In The Rural Areas. Available Statistics Show That More Than 100 Million Nigerians Live In Abject Poverty (Osibanjo, 2016). Majority Of The People Live In Less Than \$1 In Day And Hardly Take One Good/Balanced Square Meal A Day. The Healthcare System Is Very Poor. People Still Die On Daily Basis Even From Preventable Diseases (Abah, Edeh And Nwakamma, 2016). The World Economic Forum (2015) Human Capital Development Index Ranking Rated Nigeria 120 Out Of 124 Countries Studied. Most Youths Are Unemployed, According To The National Bureau Of Statistics, Unemployment Rate Increased By 8.2 Percent (Nbs, 2015). No Fewer Than 5.3 Million Youths Are Jobless In The Country While 1.8 Million Graduates Enter Labour Market Every Year (Okonjo-Iweala, 2014). Unemployment Accounts For Most Of The Socioeconomic Crimes Penetrated By Graduates In Nigeria. These Crimes Range From Armed Robbery, Prostitution, Oil Bunkering, Drug Addiction, Rape, Kidnapping, Militancy, Terrorism Among Others. It Is Against This Backdrop That This Study Became Imperative To Establish The Nexus Between Social Infrastructure Facilities And Development Of Rural Economy In Nigeria.

Statement Of The Problem

National Development Has Become A Big Challenge To Nigeria Because Of The Long Neglect Of The Contribution Of Rural Economy. All Rural Development Programmes Targeted At Repositioning The Status Of The Rural Economy Has Achieved Minimal Results Because Of Inadequate Social Infrastructural Facilities And Wrong Approaches By The Designers Of These Programmes. In Most Of The Contemporary Nigerian Rural Communities, There Is Generally Low And Inadequate Provision Of Basic Infrastructure Such As Electricity Supply, Portable Water, Agricultural Storage And Processing Facilities, Irrigation And Transportation Facilities. Also, The Rural Areas Have Restricted Access To Basic Education And Healthcare Facilities Because Of Long Distance To Traverse To Their Locations In Adjourning Towns. Majority Of The Deep Wells/Boreholes Sunk In The Rural Areas For Water Supply Are Not Functioning, Hence The Rural Households Recourse To Fetch Water From Streams/Brooks (Ogunnowo And Oderinde, 2012). This Ugly Trend Has Hindered The Development Of Rural Economy In Nigeria. It Has Negatively Affected Agricultural Production Which Is The Bedrock Of Rural Economy. Unfortunately, The Prices Of Foodstuff Have Continued To Increase Over Time. For Example, Between December 2007 And March 2009, Prices Of Palm Oil, Maize, Corn, Guinea Corn, Beans, And Garri Rose By 36, 28, 16, 12 And 8 Percent Respectively (National Bureau Of Statistics, 2009). Lack Of Infrastructure Facilities And Degrading Condition Of Life In Most Rural Communities Has Resulted To Increasing Migration/Inflow Of People Into The Capital Cities, Thus Leading To Congestion And Attendant Urban Problems Like Unemployment, Increasing House Rents And General High Cost Of Living Amidst Low Level Of Income. Poor Road Network In The Rural Areas Has Compounded The Problem Of Rural Dwellers As It Has Become Difficult For Them To Evacuate Their Farm Produce To Various Markets Where They Are Needed. The Rural Areas Lack Adequate Training In The Area Of Modern Storage Techniques, Hence They Cannot Properly Preserve Their Farm Produce. There Is Also Problem Arising From Wrong Approach To Rural Development Efforts In Nigeria. This Equally Constituted The Bane Of Sustainable Rural Economy In Nigeria. The Extent Those Who Design These Programmes Involve Prospective Or Target Beneficiaries Is Worrisome. The "Top-Bottom" Often Called Blue Print Approach To Rural Development Has Failed. Karton (1980) 
Maintained That First, There Is No "Fit" Between The Intended Beneficiaries And The Programmes, Secondly, There Is No "Fit" Between The Beneficiaries And The Assisting Organisation And Thirdly, There Is No "Fit" Between Programmes And The Organisation. This Is What Okoli (1995) Called A Blue Print Approach. A Situation Whereby A Motely Group Of Experts And Professionals (Planners, Administrators And Researchers), Sit Together, Deliberates On The Critical Needs Of The Rural People, Evaluates The Resources Available, Decides On The Project, Tasks And Programmes Needed For The Rural Population. This Has Resulted To The Failure Of Most Of These Programmes. This Failure Which Has Been Widely Acknowledged By (Ega, Et Al 1980; Sanda, Ed; 1988, Ebong, 1973 And Weitz, 1971) Is Due Not Only To The Poor Conceptualization Of Rural Development Programmes But Also Primarily To The Absence Of "Fit" In Critical Variables Involved In The Process And Inadequate Social Infrastructural Facilities.

\section{CONCEPTUAL CLARIFICATION}

Some Concepts Like Development, Sustainable Rural Economy, Infrastructure Especially Social Infrastructure, Among Others Are Defined Here To Explain Their Meanings As They Are Used In The Work And To Establish The Linkages Between The Variables.

\section{DEVELOPMENT}

Development According To Rodney (1986) Implies Increasing Skill And Capacity To Do Things, Greater Freedom, Self-Confidence, Creativity, Self Discipline, Responsibility And Material Wellbeing. Cavacho (1988) Maintains That Good Development Should Include Compliance With Human Rights And That Human Rights Would Include The Rights Of Vulnerable Groups And Poor Countries To Have Access To Appropriate Technology. For Ali (1968), Development Is One That People Oriented, Involves The People At All Stages Of The Planning And Execution Process And Is Committed To Bringing About Significant Qualitative Changes In The Lives Of All The People.

For Okpata (2004), Development As A Societal Phenomenon Is All Encompassing And Demands The Involvement Of All Sections Of The Society Simultaneously. He Further Stated That Factors In Development Can Simply Be, How Government Increases Her Capacity To Legitimize Herself, Innovate Political Changes, Respond To Demands From Pressure Groups, Diffuse Social Conflicts Through Agency Of System Maintenance, Regulation And Adaptation. The Capacities Of The Government, Manifest Itself In Either The Rate Or Level Of Literacy/Illiteracy, Poverty Or Wealth, Employment/Unemployment Rate Of Skill, Manpower/ Professionals, Infant Mortality Rate, Adequate Medicare, Provision Of Social Infrastructures (Road, Electricity, Hospitals, Good Water Etc), Environmental Sanitation Better Living Condition, Accommodation And Pension Scheme For Retired Workers(Okpata, 2004:171)

\section{SUSTAINABLE DEVELOPMENT}

The World Commission On Environment And Development (1987) Defined Sustainable Development As "Development That Meets The Needs Of The Present Without Compromising The Ability Of The Future Generations To Meet Their Needs". Development Can Only Be Sustained In An Environment Were Basic Social Infrastructural Facilities Like Access Road, Health Care Facilities, Electricity, Education, Transport Etc. Are Provided. We Therefore Define Sustainable Rural Economy To Mean The Process Of Enhancing The Capacity Of Rural Economy To Mobilize And Utilize Available Human And Material Resources Through Provision Of Social Infrastructural Facilities To Efficiently Produce Goods And Services That Can Meet The Needs Of The Present Generation Without Compromising The Ability Of The Future Generations To Meet Their Own Needs.

\section{RURAL DEVELOPMENT}

Rural Development On The Other Hand Entails Improving The Living Standards Of The Mass Of Low-Income Population-Residing In Rural Areas And Making The Process Of Their Development SelfSustaining (Lele, 1975). This Entails Community Participation To Improve Their Social Well Being. Rural Development Involves Resource Mobilization And Efficient Utilization Of Financial And Material Resources To Improve The Socio-Economic Wellbeing Of The Rural Dwellers.

\section{INFRASTRUCTURE}

Infrastructure: The Word Infrastructure Has Been Used In English Since At Least 1927 According To Online Etymology Dictionary (2012), Originally Meaning "The Installations That Form The Basis For Any Operation Or System. Infrastructure Is The Basic Physical And Organizational Structures Needed For The Operation Of A Society Like Industries, Buildings, Needs, Bridges, Health Services, And So On. It Is The Enterprise Or The Products, Services And Facilities Necessary For An Economy To Function (Sulivan And Sheffirm, 2003) 
Khan(1979) Asserted That Rural Infrastructural Facilities Can Be Classified Into Three Main Types Namely Health And Educational Facilities, Social Infrastructure-Namely Health And Educational Facilities, Community Centres, And Security Services, Institutional Infrastructure Like Credit And Financial. Therefore, Our Conception Of Social Infrastructure In This Study Encompasses The Three Dimensions Of Rural Infrastructural Facilities As Espoused By Khan (1979). The Reason Is Not Far Fetched. All These Facilities Enumerated Have Direct Bearing On The General Well Being Of The Rural People, But Most Importantly On Their Economic Activities. Rural Infrastructure Facilities Is The Bedrock /Foundation Upon Which Rural Industrialization And By Extension The Development Of Rural Economy Is Based.

\section{THEORETICAL FRAMEWORK}

There Are Theories And Approaches Which Are Believed To Enhance Rural Economic Development. This Paper Is Anchored On The People Centered Theory. The People Centered Theory To Development Views An Individual Not As Subject But An Actor Who Defines The Goals, Controls The Resources, And Directs Processes Affecting His/Her Life (Korten, 1984). The Key Elements In This Approach Are Provision Of Infrastructure Through: (A) Empowerment Of People, (B) Development Of An Administrative Process, Which Responds To The Needs Of The People, (C) Human Growth And Wellbeing (D) Equality, (E) Self-Reliance (F) Participation And (G) Sustainability. White (1987) Argued That Sustainability Is A Measure Of Lasting Quality In Development Programme. An Infrastructural Development Programme Can Be Sustained By Creating A Felt Need Among Beneficiaries About The Efficacy Of The Programme, Developing Institution Which Continually Adapt, Providing (Or Self-Generating) Resources And Building Support Among Political Elite And Community Groups.

At The Core Of This Approach Is Participation Of The People. The Importance Of Participation In The Development Of Rural Economy Cannot Be Over Emphasized. The Importance Of Participation In Rural Economy Development Is Succinctly Captured By The British House Committee On Foreign Affairs, When It Observed As Follows:

... It Has Become Increasingly Clear That Failure To Engage All Of The Available Human Resources In The Task Of Development Not Only Acts As Break On The Economic Growth But Also Does Little To Ensure The Basic Causes Of Social And Political Instability Which Pose A Constant Threat To The Gains Achieved On Economic Groups( Hapgood, 1969).

In Nigeria, As Well As In Most Developing Countries, Government Efforts At Development Has Been Directive Instead Of Participatory. This As Argued By Scholars Has Become The Major Hindrance To The Development Of The Rural Economy. For Instance, Both Idoha (2002), Eminue (2005) And Obi Nwachukwu And Obiorah (2008) Agreed That Lack Of Participation Of The Poor At Various Levels Of Anti-Poverty Programmes; "Top-Down" Rather Than "Bottom-Up" Approach, And Lack Of Involvement Of Beneficiaries In Project Design, Implementation, Monitoring And Evaluation Have Been The Problems Of Poverty Reduction Programmes In Nigeria. Also, Lawal And Hassan (2012) Maintained That The Relationship Between The Nigerian Government And The Citizenry Is That Of Limited Interaction With Members Of The Public. By Limited Interaction, We Mean That Members Of The Public, And Indeed The Poor Population Are Not Given Opportunity To Participate In Decision Making Process With Regards To How They Could Be Assisted. At Best, Beneficiaries Were Handpicked For One Scheme Or The Other.

The Relevance Of The Theory To The Study Is Based On The Fact That Cooperation Between The Government And The Rural People Will Ensure A Robust Rural Economy Through Provision Of Social Infrastructure, Electricity, Education And Training, Health Care Facilities Among Others. Government Provision Of Infrastructural Facilities Requires The Cooperation Of The People To Be Able To Provide The Right Facilities Where They Are Needed Most. Participation Is A Means Of Developing An Individual Total Personality. It Is A Learning Process. Rural Development Programmes Should Be Conceived As Learning Process Intended To Transform The Total Personality Of Their Beneficiaries. This Can Be A Sure Way To ReEngineering The Rural Economy In Nigeria. It Is Therefore, Incumbent On Those Who Design Public Policies And Programmes To Bridge The Psychological And Social Distance Between The Government And The Masses In Terms Of Involving Them In Both Formulation Of Policies And Programmes As Well As Citing Social Infrastructure Projects To Improve Their Wellbeing. Unless The People Participate Actively In A Programme, They Are Not Likely To Have A Feeling Of Fulfillment.

Re-Engineering Sustainable Rural Economy Through Social Infrastructural Facilities

Availability Of Social Infrastructure Which Includes Clean Water, Decent Housing, Environmental Sanitation, Personal Hygiene, Adequate Nutrition, Formal And Informal Education, Healthcare Facilities Among Others Is The Prerequisite For A Better Standard Of Living And Sustainable Rural Economy In Nigeria. Unfortunately, These Facilities Are Lacking In The Rural Areas. According To Madu (2007), "The Importance Of Rural Infrastructure Provision Lies In Its Capacity To Sustain Daily Activities, Quality Of Life And 
Economic Base In The Rural Areas". In Other Words, The Quality Of Life And Means Of Livelihood Of The Rural Dwellers Can Be Assessed By Analyzing The Availability Of Infrastructural Facilities At Their Disposal (Ogunowo And Oderinde, 2012). The Link Between Social Infrastructure Variables And Sustainable Development Of Rural Economy In Nigeria Are Discussed Below.

- $\quad$ Re-Engineering Rural Economy Through Provision Of Educational Services:

There Is A Strong Link Between Availability Of Education Facilities And The Development Of Rural Economy. Unfortunately, Less Attention Has Been Paid To This All Important Sector. Obiekezie And Obi (2002) Observed That Education Is Now Accepted As A Means Of Meeting Other Needs And Also Means Of Accelerating Development And Improving Productivity By Promoting Economic Growth. Development In This Sector Would Tantamount To Rehabilitation Of The Infrastructure So As To Enhance The Quality And Facilitate Raising Standards. It Will Also Involve Provision Of Equipment For Workshops, Laboratories, Modern Science And Technological Gadgets And Ensuring Their Sustained Operations, The Provision Of Textbooks, Exercise Books And Adequate Building Of Educational Institution In Order To Be Able To Engage In Effective Teaching And Learning. It Should Encompass Mass Literacy And Making Education Affordable To Majority Of Members Of The Society.

Galadima (2014) Maintains That Education Promotes Rural Productivity By Making The Members To Be Able To Decide Agronomic And Other Information So As To Carry Out Other Desirable Modern Production Practices, Basic Education Also Promotes Feeding Quality, Dignity, Self Respect, Sense Of Belonging As Well As Political Integration Of Rural People. The Above Positions Of Some Scholars Clearly Show That Education Is A Major Foundation Of Any Meaningful Development Effort. However, What Obtains In Most Rural Areas Is A Near Total Neglect Of This Sector. There Is Too, Very Apparently Poor Quality Education In Most Rural Areas In Nigeria (Ele, 2006). Ifere (1992) Notes In This Respect Too That Rural Education Is Characterized By Limited Functional Or Work Oriented Education And Disdain For Handicraft And Technical Subjects. Okoli And Onah (2002:159) Make Similar Observation As They Note Thus:

The Privilege Of Education Which, For Instance, Is Supposed To Be A Birth Right Of Every Nigerian Child Is An Illusion To Many Rural Dwellers. In Some Places, There Are No Schools At All While In Some Others The Schools Are Shabby, Ill-Equipped And Poorly Staffed.

- Re-Engineering Rural Economy Through Adequate Investment In Agriculture And Means Of Transportation Adequate Investment In Agriculture Is Necessary To Ensure Sustainable Rural Economy Since Majority Of The Country's Population Reside In The Rural Areas And Are Largely Farmers. This Has Never Being The Case Since The Basic Infrastructural Facilities To Drive This Sector Are Lacking. This Outstanding Sector Of Rural Economy Is Also Nigeria's Biggest Employer Of Labour With About 70 Percent Of The Population Engaged In It. But, Suffices To Mention That Agricultural Production In Nigeria Is Largely Concentrated In The Hands Of Peasant Farmers That Use Crude Implements And Technology. Agriculture Which Used To Be Mainstay Of The Nation's Economy In The Early Years Of Independence And Produced Enough To Feed The Nation Was Later Relegated To The Background With The Ascendancy Of Crude Oil (Petro Dollars) In The 1960s And 1970s (Ogunnovo And Oderinde 2012). There Is A Very Weak Production Structure In The Agricultural Sector That Need To Be Strengthened By Machinery Infrastructure In Order To Enhance Agricultural Production. The Nigerian Farm Landscape Is Dominated By Subsistence Farmers Who Still Use Crude Equipment And Operate Traditional Cum-Inefficient Methods. Such Large Subsistence Agricultural Sector Has Failed To Keep Up With The Rapid Population Growth. The Use Of Different Agricultural Machineries Is Still Very Low With The Entire Country Having Only 30,000 Tractors (Abba, 2009). This Means That Food Security Status Of The Nation Continues To Be Threatened With Very Low Agricultural Production.

It Is Worthy Of Note That The Provision Of An Efficient And Effective Transportation System In The Rural Areas Is Germane To The Development Of Rural Economy. However, Rural Nigeria Is Generally Characterized By Poor And Inefficient Transportation System.

According To Ogunnowo And Oderinde ( 2012), The Condition Of Transportation In Agricultural Sector Of Nigeria Is Quite Appalling. For Instance, Road Is An Asset To Any Rural Setting As It Provides The Farmers Access To Their Farm And Makes For Free Flow Of Farm Produce To Urban Markets. In Some Cases, The Bridges/Culverts Linking The Rural Areas Have Been Damaged. Such Situation Has Made Many Rural Areas Suffer Varying Degrees Of Remoteness, Inaccessibility, Relative Isolation, And Backward Effects Of Development.

Also, Storage And Processing Infrastructure As Well As Market Platforms In The Agricultural Sector Are Grossly Inadequate And Inefficient, Thus Reflecting High Level Of Pre-Harvest And Post-Harvest Losses In The Country. Due To Poor Storage Facilities, Nigerian Farmers Receive Less For Their Produce In Terms Of 
Bumper Harvest And This Impact Negatively On Productivity. Most Rural Areas Are Characterized By Deplorable Road Network And Absence Of All Year Round Reliable Roads. This Situation Is Made More Critical As The Topography Of Some Rural Communities Are Characterized By Ubiquitous Valleys And Hills And Other Geographical Challenges Like Clayey And Swampy Areas. This Poses Enormous Challenge In Road Construction (Olayiwole And Adeleye, 2005). Ele (2006), Also Observes That There Is Indeed, A Problem Of Rural Transport As Mostly All The Rural Roads Are Not Accessible And The Bridges Are Dilapidated And In Some Cases Even Non-Existent. And Since Accessibility Is A Necessity For Development, It's Lack In Most Rural Areas Holds Them Back In Dungeon Of Underdevelopment.

Re-Engineering Rural Economy Through Adequate Healthcare Provision

A Robust Health Care System Is Capable Of Improving The Rural Economy And Living Standard Of Rural People. Health Is A State Of Complete Physical, Mental And Social Wellbeing And Not Merely The Absence Of Disease Or Infirmity. Development In This Sector Would Mean Removal Of All Biological, Environmental And Social, Cultural, Psychological Factors That Could Cause Health Hazard In The Society.

Unfortunately, The Reverse Is The Case In The Rural Areas. Health Related Environmental Problems In Nigeria Vary With The Social And Economic Development Achieved By Different States And Even Different Towns And Villages Within Individual States. They Are Linked To Poverty, Absence Of Adequate Water Supply, Lack Of Sanitation Services, And Poor Housing Problems Associated With Poor Environmental Sanitation, Exposure To Communicable Disease, And Poor Personal Hygiene Predominate And Are Often Compounded By Malnutrition Which Reduces Resistance To Diseases Especially Among Vulnerable Groups Such As Children, Pregnant And Lactating Mothers And The Aged. Malaria, Cholera, Diarrhea, And Other Diseases Transmitted By Mosquitoes And Other Vectors Such As Filariasis And Parasitic Infections Like Guinea Worm And Onchocerciasis Are Still Major Public Health Problems. Onah And Okoli (2001) Observed Similarly That In Most Rural Areas Of Nigeria, No Medical Institution Of Any Sort Exists At All And That Where They Do, The People Have To Travel Very Long Distances To Get Them. The Revelation Of The National Strategic Health Development Plan (Nshdp) 2010-2015 Summarized The Health Status In Nigeria Thus:

The Health Indicators For Nigeria Are Among The Worst In The World. Nigeria Shoulders 10\% Of The Global Disease Burden And Is Making Slow Progress Towards Achieving The 2015 Targets For Health Related Mdgs. The Health Indicators In Nigeria Have Largely Remained Below Country Targets And Internationally-Set Benchmarks Due To Weaknesses Inherent In Its Health System. The Life Expectancey At Birth Has Been Reported To Be 47 Years According To The 2008 Ndhs Report. This Is Below The Least Developed Countries (Ldc) Average Age Of 53 Years. The Disability Adjusted Life Expectancy At Birth Is 38.3 Years. Nigeria Has The Highest Number Of Hiv Infected Persons In African Continent And The Fourth Highest Tb Burden In The World. One Out Of Every 7 To 8 Children Dies Before His First Birthday And One Out Of 6 Before His Fifth Birthday.

These Poor Outcomes Are Not Only Due To The High Increase In The Poverty Level But Also To The Weaknesses In The Health Sector, Especially In The Delivery Of Primary Health Care Services For Immunizable Diseases.Ogunnowo And Oderinde (2012), Maintain That The Health Status Of Rural Dwellers Is A Prosy For Measuring Their Ability And Agility To Effectively Participate In Agricultural Production. Once The Rural Farmers Are Constrained Health Wise With Dearth Of Health Services, Their Productivity Level Will Surely Drop.

The Rural Dwellers Are The Worst Hit Of This Negative Trends In The Nigerian Health Care System. This Has Not Only Affected Their Daily Life But Has Worsened The Economy Of The Rural People. Undoubtedly, Productive Activities In The Rural Areas Are Affected By The Poor Health Care Condition In The Area, And Moreso, Farming Requires Physical Energy And Rural Farmers Must Be In Good Health Before They Can Contribute Meaningfully In The Development Of Their Immediate Family And The Society At Large. Re-Engineering Rural Economy Through Adequate Poverty Reduction Programmes

There Is High Rate Of Poverty In Nigeria Which Has Affected Rural Development In Nigeria. Investment In The Agro Allied Businesses Has Been Very Low As The Rural Farmers Hardly Feed Their Families Let Alone Investing In Profitable Ventures. Data From The Federal Office Of Statistics On Poverty In Nigeria (1999) Shows That Majority Of The Poor Were Located In The Rural Areas And That Poverty Increased From 28.9\% In 1980 To 51.4\% In 1985 And Dropped To 46.0\% In 1992 But Increased To 69.8\% In 1996. Urban Poverty On The Other Hand, Increased From 17.2\% In 1980 To 37.8\% In 1985 And Increased To 58.2\% In 1996. However, In 2014 The National Bureau Of Statistics (Nbs) Revealed That The Poverty Level In Nigeria Is 69\%. This Ugly Trend Reflects In Virtually All Aspects Of Our Life. For Instance, The United Nations Development Programme (Undp) Human Development Index (Hdi) Ranked Nigeria As The $142^{\text {nd }}$ With Hdi Of 0.40 Among 174 Countries Listed In 1997. By 1999, The Country Ranked $151^{\text {st }}$ While Nigeria's Human 
Poverty Index (Hpi) Was 41.6\%, Which Placed Her Among The 25 Poorest Nations In The World (Unap, 1999).

Poverty Destroys Aspirations, Hope And Happiness. In Nigeria, As In Other Poverty Stricken Nations, This Is The Poverty One Can Feel. Poverty Affects Tolerance Of Others, Support Of Civil Liberties And Openness Towards Foreigners, It Also Affects Tolerance Of Others, Support Of Civil Liberties And Openness Towards Foreigners, It Also Affects Ones Disposition To Participate In Community Activities, Interpersonal Trust And Self Satisfaction (Amoo, 1997; Huglehart, 1997, Fairbacks 2000).Amidst Abject Poverty, Rural Economy Dwindles And Lacks Basic Support Because People Must Eat Before They Think Of Satisfying Other Needs. Government Support Policies And Programmes In This Direction Have Been Faced With A Lot Of Challenges, Poor Coordination Of Activities, Dwindling Resource Flow; Failure To Build In Sustainability Mechanisms; Lack Of Complementary Efforts From Beneficiaries; Low Accountability, Absence Of Achievable Target Setting, Absence Of Well Articulated Policy For Poverty Eradication Among Others (NapepToday, 2007). Also, Poverty Alleviation Programmes In Nigeria Which Aim At Improving The Living Conditions Of People Especially The Rural Dwellers Have Adopted Directive Approach, The Programmes Are Designed Without Involving The Prospective Beneficiaries And Has Been One Of The Major Causes Of Its Failures.

Re-Engineering Rural Economy Through Provision Of Decent Housing Schemes

Another Basic Social Infrastructure Which Is Required For Sustainable Rural Economy Is Decent Housing. However, In Rural Areas As Well As Urban Settlement, Provision Of Decent Housing Has Become A Major Social Problem In Nigeria. There Has Been Minimal Efforts Targeted At Housing Problems In The Rural Areas. If Sustainable Development Of Rural Economy Will Be Achieved, It Must Be A Holistic Process. The Activities Of The Nigerian Government Through The Federal Ministry Of Works And Housing Are Highlighted Under The Relevant Programme Areas: Providing Adequate Shelter For All, Improving Human Settlement, Management, Promoting The Targeted Provision Of Environmental Infrastructure Such As Water, Sanitation, Drainage And Solid Waste Management; Promoting Human Settlement, Planning And Management In Disaster Prone Areas, Promoting Sustainable Construction Industry Activities, And Promoting Human Resource Development And Capacity Building For Human Settlement Development. The Government Decision To Implement These Programmes Was Based On The Resolution Adopted At The First United Nations Conference On Human Settlement (Habitat) Held In Vancouver, Canada In 1976.

There Are Likely Questions That Result From The Above, One Is Has These Programmes Been Fully Implemented? Secondly, Why Is It That Nigerians Still Suffer From Poor Housing Facilities Amidst These Laudable Initiatives? Answers To The Above Questions Point To The Poor Implementation Of Government Policies Which Has Characterized The Nigerian Public Administration. According To Ekpo And Olaniyi (1995) One Of The Cardinal Objectives Of Dffri Was To Raise The Quality Of Rural Housing, As Well As The General Living And Working Environment In The Rural Areas. The Rural Housing Unit Of The Directorate Trained About 250 Technical Personnel From All The States, On How To Use Locally Available Raw Materials And Technology For Building Houses.

In 1992, A Total Of 8,024 Technical Extension Workers Were Engaged In Various Communities To Boost Rural Housing (Obeta And Okide 2013). The Truth Remains That The Deplorable Condition Of Life In The Rural Areas As A Result Of Poor Housing Has Constituted The Problem Of Sustainable Rural Economy Development. This Has Resulted To Increasing Rural-Urban Migration With The Decline In The Labour Force Of The Rural Areas With The Attendant Increased Rapid Rate Of Urbanization. The Rate Of Urbanization Has Brought With It Some Significant Problems Including Shortage Of Housing, Overcrowding, Traffic Congestion, Environmental Degradation, Inadequate Infrastructure And Services, Among Others.

\section{CONCLUSION}

In This Study, There Has Been A Concerted Effort To Establish The Nexus Between Social Infrastructure Like Education, Health Care Provisions, Housing, Poverty Reduction Programmes Etc And Sustainable Development Of Rural Economy In Nigeria. Rural Development Efforts In Nigeria Dates Back To The Pre-Colonial Era. However, The Notable Programmes Targeted At The Rural People Can Be Traced To The Post Independence Experience Like The National Accelerated Food Production Project (Nafpp), Operation Feed The Nation, Green Revolution, Better Life For Rural Women, National Directorate Of Employment Among Numerous Others. These Programmes Provided Little Or Minimal Impact To The Development Needs Of The Rural People. Hence, The Poor Standard Of Living Of The Rural People. We Equally Noted In This Study That Achieving Rural Development Goals Is A Function Of Diverse Factors Economic, Social, Political, Cultural Etc, And Most Importantly Commitment By Government To Bettering The Lots Of The People. Ijere (1990) Remarked That Rural Development Will Continue To Be A Basic Problem To Developing Countries Including Nigeria, Because Of The Following Reasons; 
Lack Of National Philosophical Base, Lack Of Integrated Pilot Demonstration, Lack Of Local Economies, Lack Of Core Project Leadership, Inadequate Community Participation, Lack Of Grassroots Planning, Inability To Optimize Local Resources And Neglect Of Community Structural ApproachWe Therefore Conclude That Sustainable Rural Economy Has Eluded The Rural Areas Consequent Upon The Inadequate Provision Of The Basic Social Infrastructural Facilities Mentioned Above Which Drives The Rural Economy And By Extension Hinders National Development Since A Robust Rural Economy Is A Prerequisite For Sustainable National Economy.

Arising From The Foregoing, The Paper Therefore Recommended As Follows:

I. Government Should Adopt A Holistic Approach That Takes Into Cognizance Of All The Aspects Of Development In Administering Development In The Rural Areas. It Has Been Observed That Most Of The Government's Efforts On Rural Development Have As Their Primary Aim, Improvement Of Food, Cash Crops And Agricultural Production (Obetta And Okide, 2013).

However, The Truth Of The Matter Is That Rural Development Is More Than Agricultural Development. Rural Transformation Involves A Comprehensive, All Round Structural And Fundamental Changes Not Just In The Physical Conditions Of The Rural Inhabitants But More So In The Mental, Physiological, As Well As Cultural Aspect Of Development.

Ii. There Should Be Robust And Regular Training And Development Of Rural Farmers On The New Techniques Of Farming And Other Agricultural Activities. Government Through This Training And Human Capacity Building Should Provide Modern Farming Equipment To Farmers For A Mechanized Agricultural Practices. It Has Been Observed That Majority Of The Nigerian Farmers, Especially In The Rural Areas Still Use Crude Farm Implements And This Has Resulted To Low Produce As They Operate At Subsistence Level. Iii. Government Should Be More Committed To The Provision Of Basic Education, Health Care Facilities, Access Road Network, Electricity Etc. This Study Has Shown That Most Rural Communities Lack Access To Clean Water, In Some Areas Where They Are Provided, They Are Inadequate. Create Incentives For Rural Growth And Employment By Improving Access To Production Resources And Institutional Services.Iv. This Paper All Recommends That More Opportunities Should Be Given To Rural People For Participation In Decisions That Govern Their Lives. Experience In The Past Has Shown That Most Programmes Targeted At The Rural People Are Directive In Nature. This Has Resulted To It's Failures. Government In Fashioning Out Policies And Programmes For Rural Development Should Involve The Target Beneficiaries In The Formulation As Well As Implementation Of These Programmes Made For Them.V. We Equally Recommended Among Others For Empowering Rural People Through Participatory And Community-Oriented Development That Is Woven Around Local Principles, Skills And Technologies, And Protecting The Environment By Generation And Facilitating Appropriate Resource Management Systems. This Also Will Enhance Sustainable Rural Economy In Nigeria.

\section{REFERENCES}

[1] Abah, E.O., Edeh, J.N. Na Dnwakamma, M.C. (2016). Challenges Of Social Welfare Services In Nigeria. European Journal Of Social Sciences, 52(1) Pp. 45-56.

[2] Abah, N. (2010). Development Administration: A Multi-Dispensary Approach. Enugu: John Jacob Classic Publishers.

[3] Abba, R. (2001). "Building A Foundation For Food Security". Tell Magazine August, 17 Pp 34-43.

[4] Abumere, S.I. (1997). "Some Thought On Gis Cartography And Sustainable Development In Isilkuoria (Ed) Castography And Geographic Information Systems For Sustainable Development Pp. 1-12.

[5] Cohen, J.M. And Uphoff, T.N. (1977). Rural Development Participation: Concepts And Measures For Project Design, Implementation And Evaluation. Ithaca, New York: Cornell University

[6] Ekpo, A.H. And Olaniyi, O. (1995). Rural Development In Nigeria: Analysis Of The Impact Of The Directorate For Food Roads And Rural Infrastructure (Dfrri) 1986-93. In Eboh, E.C., Okoye, C.U. And Ayichi, D. (Eds); Rural Development In Nigeria Concepts Processes And Prospects. Enugu: Auto-Centur Publishing Company.

[7] Ele, C. (2006). Evangelization Through Rural Development. Nsukka: Greate Ap Publishers Ltd.

[8] Eminue, O.E. (2005). Public Policy Analysis And Decision Making. Lagos: Concept Publications.

[9] Hapgood, D. (1969). The Role Of Popular Participation In Development: Report Of A Conference On The Implementation Of Title Ix Of The Foreign Assistance Act, June 24-Ugust 12, Cambridge Mass. M.I.T. Press.

[10] Ijere, M. (1992). Leading Issues In Rural Development. Enugu: African Ventures

[11] Ijere, M.O. (1990). The Challenges Of Rural Development In Nigeria. In Ikeme, A.I. (Ed), The Challenges Of Agriculture In National Development. Enugu: Optional Computer Solutions, Ltd. 
[12] Korten, D.C. (1980) “Community Organization And Rural Development: A Learning Process Approach In Public Administration Review, September/October.

[13] Lasisi, K. M. (1992) “A Critical Evaluation Of The Directorate Of Foods, Roads And Rural Infrastructure (Dfrri) In Nigeria”. An Unpublished M.P.A .Research Project Submitted To The Department Of Political Science And Administration, University Of Maiduguri.

[14] Lawal, A.O. And Hassan, U.S. (2012). "Public Service And Poverty Eradication In Nigeria: An Assessment Of National Poverty Eradication Programme (Napep), 2001-2011”. Public Administration Research, (1) 1 Issn 1927-517 E-Issn 1927-5188 Published By Canadian Centre Of Science And Education.

[15] Lele, U. (1975). The Design Of Rural Development Lesson From Africa. London: The Johns Hopkins University Press.

[16] Lele, U. And Adu-Nyako, K. (1990). Interpretation Strategy Approach For Poverty Alleviation: A Paramount Priority For Africa. African Development Review 3(1); 1-29.

[17] National Bureau Of Statistics (2014). Poverty Profile In Nigeria.

[18] Nwachukwu, L. And Onwubiko, O. (2008). "Poverty Alleviation As A Policy Problems In Nigeria: Lessons Of Experience And Perspective For Solution”. African Journal Of Political And Administrative Studies (Ajpas) 4(1), Pp. 251-270.

[19] Obeta, K.C. And Okide, C.C. (2013). Rural Development Trends In Nigeria: Problem And Prospects. International Journal Of Research In Arts And Social Sciences (Ijrass). Pp 18-32.

[20] Obi, E.A., Nwachukwu, L.C., Obiora, A.C. (2008). Public Policy Analysis And Decision Making. Onitsha: Book Point Educational Limited.

[21] Ogunnowo,C.O. And Oderinde, F.O. (2012)" Sustainable Development And Management Of Infrastructure For Effective Transformation Of Rural Communities In Nigeria. Implications For Food Security. Ozean Journal Of Social Sciences 5(3).

[22] Okoli, F.C. (1995). "Pathologies Of Local Government Administration: Community And Rural Development Administration Programmes" In Ikejiani-Clark, M. And Okoli, F.C. (Eds.) Local Government Administration In Nigeria. Current Problems And Future Challenges. Lagos: Mangroove Publication Limited.

[23] Okoli, F.C. And Onah, F. (2002). Public Administration In Nigeria: Nature, Principles And Application. Enugu: John Jacobs Publishers Ltd.

[24] Okpata, F.O. (2004). Public Administration Theory And Practice: An Integrated Approach. Enugu: Cheston Agency Ltd.

[25] Ugwuanyi, B.I. And Chukwuemeka, E.O. (2013). "Enhancing Rural Development In Nigeria: Periscoping The Impediments And Exploring Comparative Measures. Singaporean Journal Of Business Economics, And Management Studies. 1(8), 2013. Pp 1-7.

[26] United Nations Development Report (2001), Nigeria Human Development Report 2000/2001 Millennium Edited (Undp) Lagos. 